\title{
NEGOTIATION OF AN OVERDUE BILL OF EXCHANGE OR PROMISSORY NOTE
}

\author{
R. T. DONALD*
}

\begin{abstract}
The author discusses the equities that attach to a bill or note, particularly the defects in title enumerated in the Bills of Exchange Act, and those that exist between the parties; in the context of how they affect the parties to the instrument. Special attention is paid to the holder of an overdue bill of exchange or promissory note.
\end{abstract}

The position of a person who takes an overdue bill of exchange is set out in Section 70 (1) of the Bills of Exchange Act, R.S.C. 1952, c. 15, in this manner:-

When an overdue bill is negotiated, it can be negotiated only subject to any defect of title affecting it at its maturity, and thenceforward no person who takes it can acquire or give a better title than that which the person had from whom he took it.

While the section refers only to a bill it is equally applicable to a promissory note. ${ }^{1}$

The foregoing section of the Act expressly recognizes the negotiability of an overdue bill, in the sense that it is transferable. In that sense the instrument is negotiable equally before and after maturity.

With the development of commerce, particularly international commerce, some means had to be found other than the delivery of currency for the settlement of accounts. The substitute had to be something that would be akin to currency otherwise it would not win acceptance. If it was to take the place of currency, it had to be as nearly as possible of the nature of currency. This was partly achieved by the notion that the obligation of the primary obligor on the instrument would remain as the instrument passed from person to person, even though there had been no contractual relations between them. But if a bill of exchange was to be a substitute for currency, it must be capable of circulation, free, so far as possible, from any infirmities that might have become attached to it at the time of its creation or subsequent thereto. To the extent that this was achieved, a party to the instrument could obtain a better title than the person from whom he took it. This is the second sense in which the word negotiable is used. The instrument must not only be transferable from a holder to another person, but it must so far as was practical be transferable so as to confer a clear title to it.

The law merchant and the common law developed rules to promote circulation of bills of exchange. These rules with some modifications are now embodied in the legislation relating to bills of exchange and promissory notes in Canada and other jurisdictions.

So long as the instrument was not passed beyond the original parties to it, there was no necessity to give it a special position. But when an instrument that was regular and complete on its face passed

\footnotetext{
- M.B.E., Q.C., LL.B. (Dalhousie), F.C.I.S., Professor, Faculty of Law, Dalhousle University.

1 Bllls of Bxchange Act, R.S.C. 1952, c. 15, s. 186.
} 
beyond the original parties, the person taking it bona fide and without notice of any defect in title had to have the greatest assurance possible of his title. It was recognized, however, that such a holder who came to be known as a holder in due course, could not fairly be given an unassailable title if, in its inception, no obligation had been created in law. In general, however, this only precluded him from recovering against the person who appeared to be the original obligor on the instrument.

As against those who later became parties to the instrument he was given a large measure of protection under the principle of estoppel. ${ }^{2}$ The favourable position of a holder in due course is in contrast with the inferior position of a holder who takes the instrument after maturity, who, with one exception, receives it subject to any defect of title affecting it at its maturity.

The use of the words "defect of title" in Section 70(1) of the Bills of Exchange Act is in contrast with the words "defect in the title" in Section 56(1) (h) where, in prescribing the conditions for a holder to qualify a holder as a holder in due course, it is stated as one of the conditions that at the time the instrument was negotiated to him he had no notice of any "defect in the title" of the person who negotiated it to him. Section 56(2) follows with the provision that in particular the title of a person who negotiates a bill is "defective" within the meaning of the Act when he obtained the bill or its acceptance under certain enumerated circumstances. Then in Section 72 it is provided that a person who takes a bill that is not overdue but with notice of its dishonour, takes it subject to any "defect of title" attaching thereto at the time of its dishonour.

Basically Section 56 covers the situation of a holder taking a bill before it is overdue and without notice of any previous dishonour while Sections 70 and 72 deal with the situation where a holder takes it after it is overdue, or, not being overdue, with notice of dishonour. If the holder taking before maturity and without notice of dishonour also meets the other conditions of Section $56(1)$ he is unaffected by the fact that the title of the person who negotiated the bill to him is defective. On the other hand it is reasonably clear that holders within the contemplation of Sections 70 and 72 are to be subject to the disabilities from which a holder who qualifies under Section 56 is to be free. In other words, the disabilities embraced by the words "defect in the title" in Section 56 are the same as the disabilities embraced by the words "defect of title" in Sections 70 and 72; consequently no significance should be attached to the difference in the wording in these sections. Strength is added to this conclusion by the wording of Section $74(\mathrm{~b})$ which establishes the rights and powers of holders of a bill, and in that section a holder in due course is said to hold the bill free from any "defect of title" of prior parties.

The Act does not contain a definition of "defect in the title" or of "defect of title". The enumeration in Section $56(2)$ of instances in which the title of a person who negotiates a bill is defective is generally

2 This principle has been carried into the Bills of Exchange Act, R.S.C. 1952, C. 15 , for example, the provisions of Sections 129 and 133 are in substance statutory estoppels. 
regarded as not being exhaustive. ${ }^{3}$ The use of the words "in particular" indicates that there may be circumstances other than those enumerated, that will give rise to a defective title.

The infirmity attaching to a bill when it is negotiated after it is overdue is stated first in general terms in Section $70(1)$, to wit, that "it can be negotiated only subject to any defect of title affecting it at its maturity". To this point a holder who takes a bill from a holder in due course after maturity would appear to take subject to any defect of title and not be entitled to take advantage of Section 57 and shelter under a holder in due course. The concluding part of Section 70(1), "and thenceforward no person who takes it can acquire or give a better title than that which had the person from whom he took it" indicates that this is not the case. This conclusion is reinforced by judicial decisions." Nor is he subject to all of the defences that are available against his indorser, but only those defences that affected his predecessor's title. ${ }^{5}$

The phrase "defect of title" was introduced into the Bills of Exchange Act when it was enacted in England in 1882 in lieu of the old expression "subject to equities" because the statute was to apply also to Scotland and the old phrase was not known to Scotch law. ${ }^{6}$

It is generally conceded that the Bills of Exchange Act, 1882 passed in England and adopted with few modifications in Canada was intended to be substantially a codification of the common law. In The Governor And Company of the Bank of England v. Vagliano Brothers ${ }^{7}$ Lord Herschell, however, pointed out that in construing the Act the starting point should not be an examination of the common law on the assumption that it was probably intended to leave it unaltered. $\mathrm{He}$ expressed it thus:-

I think the proper course is in the first instance to examine the language of the statute and to ask what is its natural meaning, uninfluenced by any consideration derived from the previous state of the law, and not to start with inquiring how the law previously stood, and then, assuming that it was probably intended to leave it unaltered, to see if the words of the enactment will bear an interpretation in conformity with this view.

No one can quarrel with this general approach to the construction of a statute. It is significant, however, that the particular instances set out in Section $56(2)$ as constituting a defect in title are matters which at common law would have been treated as an equity attaching to the instrument.

In Edcal Industrial Agents Ltd. vs. Redl \& Zimmer, ${ }^{8}$ where the defence set up against a remote holder for value who took the instrument after maturity was defect of title, Johnson, J.A., in giving the

3 Byles, The Law of Bills of Exchange (22nd edition) 206: Chalmers, Bills of Exchange (13th edition) 98, and Falconbridge, Banking and Bills of Exchange (7th edition) 672 state that the list is or may not be exhaustive.

+ Gauthier y. Reinhart (1904) 26 Que. S.C. 134, and cases before the enactment of the Bills of Exchange Act in England, for example, Chalmers v. Lanion (1808) 1 Camp. 383, 170 E.R. 993; Fairclough v. Pavia (1854) 9 Exch. 690, 156 E.R. 296. 5 By!es, The Law of Bills of Exchange (22nd ed.) at 194."

"It is a fair inference that the phrase "defect of title" was intended to be the equivalent of "subject to equities". In Alcock v. Smith [1892] 1. Ch. 238 at 263 Lindley, L. J., expressed it thus:

Now, 'defect of title' is a phrase introduced into the Bills of Exchange Act in lieu of the old expression 'subject to equities,' which is an expression not adopted because the Act applies to Scotiand as well as to England, and 'subject to equities' is an expression not known to Scotch law.

7 [1891] A.C. 107

8 (1967) 60 D.L.R. (2d) 289. 
reasons for the majority of the Alberta Supreme Court, Appellate Division, reviewed what was in his opinion the position of a person who took an overdue bill at common law. His conclusion was that the common law position was as was stated in the early cases in England of Brown v. Davies, ${ }^{9}$ Tinson v. Francis, ${ }^{10}$ and some later cases that predated the enactment of the Bills of Exchange Act in England. In referring to Tinson v. Francis, Johnson, J.A., remarked in the Edcal case at 293:

Lord Ellenborough with his usual conciseness states the rule thus:

"After a bill or note is due, it comes disgraced to the indorsee, and it is his duty to make enquiries concerning it. If he takes it, though he gives a full consideration for it, he takes it on the credit of the indorser, and subject to all the equities with which it may be encumbered.'

In re Overend, Gurney, \& Co. Ex parte Swan, Sir Roger Malins, V.C., commenting on the doctrine thus laid down by Lord Ellenborough said as follows: ${ }^{11}$

The general proposition that a person who takes an accommodation bill after it has been dishonoured, cannot be in a better situation than the drawer as against the acceptor, cannot now be maintained. It was admited by Mr. Roxburgh, in his argument for the official liquidator, that the law is now settled that an indorsee for value of an accommodation bill after dishonour can recover against the acceptor, though the drawer himself could not have done so; and the authorities on that point most distinctly support that admission. The contrary was certainly formerly held, and it may be considered that Ex parte Lambert (13 Ves. 179) was supported by the current of authority at the time it was decided. In Tinson v. Francis (1 Camp. 19) Lord Ellenborough uses this expression (this being in 1807, the decision of Lord Erskine being 1806): 'After a bill or note is due it comes disgraced to the indorsee, and it is his duty to make inquiries concerning it. If he takes it, though he gives a full consideration for it, he takes it on the credit of the indorser, and subject to all the equities with which it may be incumbered.' The same doctrine is also laid down in Brown v. Davies (3 T.R. 80), decided by Lord Kenyon, Mr. Justice Buller, and the other distinguished Judges of the Court of Queen's Bench at that time.

This, however, is distinctly overruled by the authorities commencing in the following year, and uniform down to the present time. In Charles v. Marsden (1 Taunt. 224, 225), which was a case decided in 1808, only two years after the decision of Lord Erskine in 1806, the marginal note correctly states the decision: 'It is not, of itself, a defence to an action by the indorsee of a bill of exchange to plead that it was accepted for the accommodation of the drawer, without consideration, and was indorsed over after it became due.'12

Later in the same case the Vice Chancellor sets out the following observation by Cresswell J. in Sturtevant v. Ford: ${ }^{13}$

It is said that the indorsee of a bill which is overdue takes it subject to all the equities. Perhaps a better expression would be that he takes the bill subject to all its equities. ${ }^{14}$

An illustration of the nature of an equity that attaches to the bill is provided in Holmes v. Kidd. ${ }^{15}$ In that case the acceptor of a bill

o (1789) 3 T.R. 80, 100 E.R. 466.

10 (1807) 1 Camp. 19, 170 E.R. 861.

12 See also in 6 Eq. 344 at $357-358.6$. Ch. App. 41, in which Sir G. M. Gifford, L.J. sald that the law could not be better stated than was done by Vice-Chancellor Malins in his judgment in Ex parte Swan (1863) L.R. 6 Eq. 344.

13 (1842) Man. \& G. 101 at 106, 134 E.R. 42 at 44.

14 See also a commentary in (1870) 49 Law Times 122 at 123 under the title of Equities Attaching to Overdue Bills of Exchange. After noting the doctrine laid down in Tinson v. Francis (1807) 1 Camp. 19.170 E.R. 861 and approved in Brovon Davies (1789) 3 T.R. 80, 100 E.R. 466, the commentator adds: "Within twelve months of that decision (Brown v. Davies) however, the current authority turned".

(The commentator concludes with the express approval by Lord Justice Gifford in Re European Bank [1872] L.R. 8 Ch. App. 41 of the statement of the law in in Re European Bank [1872] L.R. 8 Ch. App. 41 of the statement of the law in
Ex parte Swoun (1868) L.R. 6 Eq. 344 the decision of the latter case "will therefore settle all doubts upon a most important branch of the law affecting negotiable instruments.")

16 (1858) 3 H. \& N. 891, 157 E.R. 729. 
had deposited with the drawer certain canvas giving him the right to sell it as the means of providing payment for the bill. The bill was endorsed when overdue and afterwards the canvas was sold by the drawer, but the proceeds did not wholly pay the bill. The endorsee sued for the amount of the bill and it was held that his claim was subject to the agreement made between the drawer and acceptor as an equity attaching to the bill. In the course of his reasons for his decision Crompton J. said: ${ }^{16}$

Upon the concoction of this bill it was agreed that it was not to be paid if the canvas was sold. That agreement directly affects the bill and was part of the consideration for it. The case, therefore, differs from that of a right of set-off against the endorser, which is merely a personal right not affecting tht bill. In the present case the equity directly attaches to the bill.

The view that the doctrine laid down in Tinson v. Francis ${ }^{17}$ and Brown v. Davies ${ }^{18}$ was not accepted in later decisions in England, and in fact was dissented from, is supported by M. D. Chalmers in his Digest on the law of Bills of Exchange, Promissory Notes and Cheques published in 1878, just four years prior to the enactment of the Bills of Exchange Act in England. ${ }^{10}$ In his Digest, Chalmers included a table of cases that in his opinion had been overruled, doubted or explained. Brown v. Davies is included in this list as having been overruled by Ex parte Swan, and Tinson v. Francis as having been dissented from in the same case. It would appear clear, therefore, that the conclusion of the majority of the court in Edcal Industrial Agents Ltd. v. Redl and Zimmer ${ }^{20}$ is weakened in so far as it is based on the conclusion that the common law was correctly set out in Brown v. Davies and Tinson v. Francis.

Absence or failure of consideration or breach of the underlying contract that gave rise to the creation of the bill are not included among the defects of title enumerated in Section 56(2) of the Act. A distinction in these areas must be made between immediate parties, meaning parties who are in direct relation to each other, and all other parties who are remote parties. The following summary of the law as to absence or failure of consideration given by Chalmers ${ }^{21}$ is supported by the relatively small number of judicial decisions in which these defences have been raised:

1. Mere absence of consideration, total or partial, is a matter of defence against an immediate party or a remote party, who is not a holder for value, but it is not a defence against a remote party who is a holder for value. An accommodation party is liable to a holder for value, who takes a bill knowing him to be such.

2. Total failure of consideration is a defence between an immediate party, but is not a defence against a remote party, who is a holder in due course.

In his commentary on this rule Chalmers adds that failure of consideration it seems is a defence against a remote holder for value with notice. The reason that he gives for this conclusion is that it would be in the nature of a fraud for a holder to negotiate

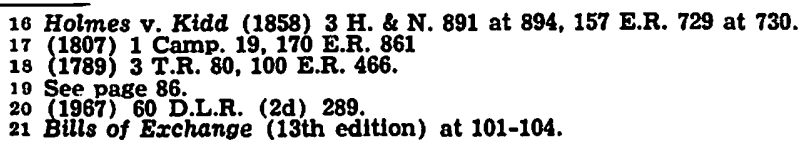


a bill when he knows that the consideration on which he received it has failed. But he adds the query: Might there not be cases in which it would not be fraud to do so?

3. Partial failure of consideration is a defence pro tanto against an immediate party when the failure is an ascertained and liquidated amount, but not otherwise. It is not a defence against a remote party who is a holder for value.

Falconbridge on Banking and Bills of Exchange (7th edition) sets out the rules substantially in the same manner. ${ }^{22}$ In his commentary he states that original absence of consideration is not a defect of title or equity attaching to the instrument, adding: "The statute seems to uphold this view, since absence of consideration is not one of the defects of title specified in s. 56". ${ }^{23}$ This is hardly consistent with the commentary in the same treatise that the list of defects in Section 56(2) may not be exhaustive. ${ }^{24}$ Falconbridge notes, however, that the cases that he cites in support of his conclusion that original absence of consideration is not a defect of title were concerned with accommodation parties who are now expressly provided for in Section 55 of the Act. $\mathrm{He}$ adds that "The general principle, that absence of consideration is not a defect of title, seems to be implied in s. 54, which defines a holder for value."2s

The conclusion that the list in Section 56(2) may not be exhaustive is supported by internal evidence by the use of the words "in particular" in the sub-section. The door is left open for the inclusion of other defects of title, but it is submitted that to be a defect in title it must be an equity that attaches to the bill. It is clear, however, that when the Bills of Exchange Act was passed in England the absence or partial failure of consideration, or total failure of consideration, as such, were not considered to be equities that attached to the instrument. If they had been recognized as such equities, they would undoubtedly have been enumerated as defects of title. The omission of total failure of consideration from the list of defects of title in the Act when the holder has notice of the failure is explained by the view that it was considered fraudulent to negotiate an instrument when the holder knew that the consideration on which he received it has failed. Fraud having been included as a defect of title it would have been redundant to include as well total failure of consideration with notice.

The rules as enumerated in Chalmers and Falconbridge do not present much difficulty as between immediate parties and need not be examined in depth. The position as between immediate parties to a bill is substantially, but not entirely, the same as the rights between an assignor and an assignee of a chose in action. The rule that a partial failure of consideration is a defence pro tanto against an immediate partly only when the failure is an ascertained and liquidated amount, is consonant with the limited right of set-off under the first legislation in England giving a right of set-off. However, if the rule as applied to bills of exchange was in fact only a procedural 
bar to set-off, with the extended right of set-off and counterclaim for an unliquidated or unascertained amount, permitted by the Judicature Acts, there is no longer any justification for the rule as between immediate parties.

The view that it may only have been a rule of procedure was expressed in Oscar Harris, Son \& Co. v. Vallarman \& $\mathrm{Co}^{26}$ On the other hand, the view has been expressed that the rule is a rule of law applicable to bills of exchange.

In the Oscar Harris case, the judge in the first instance had ordered that a plea of the acceptor (defendant) of certain bills in an action taken by a person holding them for collection for the drawer be struck out. The bills had been given for the purchase price of certain machines and the buyer alleged that they were defective in breach of a condition of the sale. Since the plaintiff was merely holding the bill for the drawer, he was in fact in the position of an agent and the action should be viewed as one between immediate parties.

On appeal from the judge's order the Court of Appeal stated the rule relating to partial failure of consideration in the words of Chalmers: ${ }^{27}$

Partial failure of consideration is a defence pro tanto against the immediate party when the failure is an ascertained and liquidated amount, but not otherwise.

The Court of Appeal reversed the order of the judge and Slesser, L.J. who gave the reasons of the court said in part as follows: ${ }^{28}$

For myself, I would express no concluded opinion upon what may be decided as to the ultimate rights of the appellants in this case, and I assume for this purpose that the allegations in the defence are true as to the quality of this machine.

However that may be, I think that, in the present state of the law, since the Supreme Court of Judicature (Consolidation) Act, 1925, it is at any rate very arguable that the defendants may claim as a reduction of the liability under the bills the loss and damage by way of set-off, as mentioned in the defence. I would prefer, as I say, to express no concluded opinion, because the matter is one which may require considerable argument, and I do not wish to prejudge the result of that part of the trial. I find it quite impossible, however, to say that such a statement does not disclose any reasonable cause of action, and $I$ think that the judge was wrong in preventing the defendants from making this claim of set-off.

The second view was set out in James Lamont \& Co. Ltd. v. Hyland, Ltd. ${ }^{28 a}$ In this case the drawer sued the acceptor of a bill of exchange that it had accepted for the amount of the contract price on the repair of a ship. The acceptor alleged that the drawer had failed to complete the repairs within the stipulated time and that it had a claim for loss and damage in excess of the amount of the bill. In proceedings by the drawer for summary judgment, the acceptor opposed the proceedings indicating an intention to set up a counterclaim for damages. The master of the court gave the plaintiff leave to sign judgment subject to a stay of execution pending the trial of the counterclaim. On appeal, the judge in chambers dismissed the defendant's appeal and allowed the plaintiff's appeal against the stay. On a further appeal, the Court of Appeal refused to disturb the exercise by the Judge of the discretion vested in him to give leave to the plaintiff to sign immediate judgment

$26[1940] 1$ All E.R. 185, 162 L.T. 212.

27 Id, at 187 .

28 Id. at 187-188.

288 [1950] 1 All E.R. 929. 
without a stay. Roxburgh, $J$. in giving the reasons for the Court of Appeal, said in part as follows: ${ }^{29}$

.. . This court has recently decided in Morgan \& Son, Ltd. v. S. Martin Johnson \& Co., Ltd. ([1948] 2 All E.R. 196) that where the matters relied on by the defendant, although not strictly matters of defence, would before the Judicature Acts have been regarded by a court of equity as ground for relief by way of equitable set-off, the proper order to make under Ord. 14 procedure as a general rule is that the defendant have unconditional leave to defend and not that the plaintiff recover judgment with execution stayed until the trial of the counterclaim.

The question raised in the present appeal is whether this rule applies to an action between immediate parties to a bill of exchange, where the matters relied on by the defendant afford no defence under the Bills of Exchange Act, 1882. In such cases, although it is not easy wholly to reconcile the authorities, a rule more favourable to the plaintiff has in general prevailed, the court treating the execution of a bill of exchange either as analogous to a payment of cash, or as amounting to an independent contract within the wider contract in pursuance of which it was executed, and not dependent as regards its enforcement on due performance of the latter. Counsel for the plaintiffs cited in particular three cases which illustrate this rule or tendency. Some of them are pre-Judicature Act and pre-Order 14 cases. ${ }^{29 a}$

After reviewing the cases, Roxburgh, J. continued: ${ }^{30}$

Having regard to the tenor of the authorities summarized above in cases where the action is on a bill of exchange, it is impossible to say that in giving liberty to sign immediate judgment without a stay the learned judge in chambers was guilty of an improper exercise of the discretion vested in him. In our view, the appeal fails.

In both of the last mentioned decisions the Court of Appeal appeared to regard the right of an acceptor of a bill of exchange to set up a counterclaim against the drawer as a matter of discretion for the trial judge. No indication, however, is given as to the circumstances that would justify the exercise of the discretion one way or the other.

In Canada the defence of partial failure of consideration as between immediate parties was considered in the Ontario Divisional Court in The Goldie and McCulloch Company (Limited) v. Harper. ${ }^{31}$ Rose, J. in giving the reasons for the court, said: ${ }^{32}$

It is not an answer because it is not a total failure of consideration. It is not an answer as to part because the sum, assuming a partial failure, is not liquidated or ascertained.

The position of a remote party with respect to a partial failure of consideration is conclusively settled by the decision of the Supreme Court of Canada in Ashley Colter Ltd. v. Scott. ${ }^{3 s}$ The facts were that a company, Ashley Colter, Ltd., had agreed to buy from one Gordon G. Scott, all the merchantable white pine lumber piled at a certain named location, estimated at 250,000 feet. The buyer company agreed to accept drafts up to $\$ 5,000$ payable 30 days from the date of shipment. During the performance of the contract and after some drafts had been accepted, by agreement between the parties promissory notes instead of drafts were given. The lumber actually shipped fell short of the estimate and consequently the balance payable under the terms of

29 Id., at 931.

29a In the course of the statement of h/s reasons for his decision in Fielding and Platt Ltd. v. Najjar [1969] 2 ALL E.R. 150 at 152 (C.A.). Lord Denning M.R. put it more strongly in these words: 'We have repeatedly sald in' this court that a bill of exchange or a promissory note is to be treated as cash'.

80 Id. at 932 .

31 (1899) 31 O.R. 284.

82 Id., at 290 .

83 [1942] 3 D.L.R. 538. See also Banque de la Societe Generale de Belgique v. McKissock [1961] O.W.N. 121 (Ontario High Court) to the same effect. 
the contract for the lumber shipped was considerably less than the total amount of the notes, on which suit was taken. Gordon G. Scott had died before the last of the lumber had been shipped and the notes were then held by the Royal Bank of Canada, at its Fredericton branch, where they had been discounted. Before the notes were discounted, the bank required and received the endorsement of the plaintiff, Scott. After the maturity of the notes the bank called on the plaintiff to pay under his endorsement and he did so with knowledge of the contract. The trial judge in the Supreme Court of New Brunswick found that the plaintiff had given no consideration. On appeal there were differences of opinion on this point but the court by a unanimous decision allowed full recovery on the outstanding amounts of the notes, holding that partial failure of consideration was no defence to an action by a party who became an endorser after maturity with knowledge of the partial failure of consideration. ${ }^{34}$

The defendant appealed to the Supreme Court of Canada and that court by unanimous decision dismissed the appeal. In that Court Sir Lyman P. Duff, C.J.C. did not give extended reasons but simply said that the appeal should be dismissed on the grounds given by the Chief Justice of New Brunswick (Baxter, C.J.) who had based his decision on alternative grounds: $(1)^{35}$

Considering it as a partial failure of consideration-which must be predicated upon what is to me rather inconclusive evidence as to quantities, it is clear that a remote party who has given value for the instrument may be entitled to receive payment in full and is not disabled by partial failure of consideration.

and (2),,$^{36}$

The Bank is a holder in due course. The plaintiff is a holder for value. But even if it were not so, s. 57 applies.

Accordingly, the plaintiff could shelter under the Bank which was a holder in due course.

Rinfret J. gave extended reasons for his decision, with which Kerwin and Taschereau JJ. concurred. The significant parts of the reasons given by Rinfret J. are as follows: ${ }^{37}$

There cannot be any doubt that there was consideration for the drafts given by the appellant, and so, therefore, for the promissory notes which replaced them. The giving of the drafts was part of the obligations undertaken by the appellant under the agreement with Gordon Scott. They were part of the consideration for the contract itself. No restriction was stipulated between the immediate parties to the contract as to the right of Gordon Scott to negotiate these drafts or, subsequently, the notes.

Immediately upon accepting the drafts, the title to the lumber passed to and remained in the appellant.

The agreement merely called for an adjustment after all the shipments of lumber had been made, if it should happen that the lumber fell short of the quantity estimated. To all purposes, the acceptance of the drafts was the equivalent of a payment on account of the total purchase.

As a consequence, there was no defect of title affecting the drafts or notes at their maturity, nor were the notes subject to any inherent equities which might have affected the rights of a holder for value.

Assuming there be partial failure of consideration between the immediate parties to a bill, such a failure cannot affect the title of remote parties (See Lord Denman C.J., in Robinson v. Reymolds, 2 Q.B. 196, 114 E.R. 76, of which the Lord Chancellor said, in Thiedemann v. Goldschmidt, 1 De G.F. \& J. 4,

84 Scott v. Ashley Colter Ltd. [1941] 2 D.L.R. 192.

35 Id., at 195.

86 Id., at 197 .

3i Ashley Colter Ltd. v. Scott [1942] 3 D.L.R. 538 at 541-542. 
45 E.R. 260, that the authority had never been questioned; Byles on Bills, 18th ed., p. 137).

The bank gave value for the bills or notes, and it was a holder in due course. The respondent was a holder for value. When the notes were charged back to the account of the respondent, from all points of view, the respondent gave payment for them. He was himself an accommodation endorser who had received no value therefor (Bills of Exchange Act, s. 55).

The title of the respondent to the notes was in no way defective within the meaning of the Act. He had not obtained them 'by fraud, duress or force and fear, or other unlawful means, or for an illegal consideration . . . or under such circumstances as amount to a fraud' [s. 56(2)].

Further, assuming that the notes were charged to the respondent's bank account after their maturity, the respondent derived his title to the notes through a holder in due course; and, under s. 57 of the Act, not being himself a party through a fraud or illegality affecting the notes, he had all the rights of that holder in due course as regards the appellant which signed the notes. Accordingly, the respondent, having been compelled as endorser to pay the notes, may recover the amount thereof from the appellant, which was the promissor thereof (s. 135). To escape liability, as was said by the learned Chief Justice of the Appeal division, it was necessary for the appellant 'to show that tht plaintiff is controlled by an equity inherent in the transaction and which is not compatible with the assignment of the notes after they have become due-if they are to be treated as overdue before assignment.' [ [1941] 2 D.L.R. 192 at pp. 199-200] No such equity existed in the present case. The respondent's endorsements on the notes were not given pursuant to any agreement in respect of the appellant.

When it is stated that the endorser of an overdue bill takes it subject to its equities, that means: the equities of the bill, not the equities of the parties. He does not take it subject to a mere 'right not inherent in a contractual relation represented by the bill' (The Swan case (1868) L.R. 6 Eq. 344, Malins V.C., at 359).

In Edcal Industrial Agents Ltd. v. Redl and Zimmer ${ }^{38}$ the majority of the court in the Appellate Division of the Supreme Court of Alberta faced with this decision held that a breach of contract did not constitute a partial failure of consideration. The facts were that a company, Columbia Motel Development Corp. Ltd. had contracted to construct a motel for Redl. Before the work was finished Redl gave the company a promissory note payable in installments for the balance payable under the contract on the assurance that the work was guaranteed. At that time the heating and sewage systems were not satisfactory. After default had been made in the first two installments, the contractor, Columbia Motel Development Corp. Ltd., endorsed the notes to Edcal Industrial Agents Ltd., without recourse. At that time the difficulties in the heating system had been corrected, but the sewage system was not working satisfactorily. There was no evidence that the endorsee of the note knew of the defects in this system.

Johnson, J. A., as already mentioned in giving the reasons for judgment for the majority of the court reviewed at length several decisions of the courts in England pre-dating the enactment of the Bills of Exchange Act, in 1882, including the rule laid down by Lord Ellenborough in Tinson v. Francis. ${ }^{30}$

Johnson J.A. then continued: ${ }^{40}$

The 'equities' used in this quotation and referred to in most of the cases dealing with this subject were generally the defences which would have been available to the maker against the payee of the note. I said 'generally' because there were defences which were personal, such as a right of set-off of a debt unconnecttd with the transaction which gave rise to the note. But all defences which the payee had against the maker arising out of the

88 (1967) 60 D.L.R. (2d) 289.

80 (1807) 1 Camp. 19, 170 F. R, 861 .

40 Edcal Industrial v. Redl \& Zimmer (1967) 60 D.L.R. (2d) 289 at 293. 
dealings which resulted in the note were equities which followed the note into the hands of the endorsee who took it after maturity.

There would appear to be no doubt that what would now be called breaches of contract were such equities. ...

Later in his judgment, Johnson J.A. concludes that before the passing of the Judicature Acts a claim for damages for breach of contract was not an equity which followed into the hands of a holder who was not a holder in due course because of procedural difficulties. The procedural difficulties had in his opinion been overcome by the Judicature Acts, and in support of this he refers to Oscar Harris, Son \& Co. v. Vallarman \& Co.41 This, as already pointed out, may be a valid conclusion in an action between immediate parties; but it cannot be regarded as supporting the conclusion that a counterclaim under a contract is a defect of title and therefore can be raised successfully against a remote party.

The majority of the Alberta Court concluded that breach of contract is not a partial failure of consideration "as that phrase is known in the law", ${ }^{42}$ and that, accordingly, the decision in the Ashley Colter case $^{43}$ was not a bar to finding that a breach of contract was a defect of title constituting a good defence against the holder for value who had taken the instrument after maturity. As to the Ashley Colter case, Johnson, J.A. said: "I do not consider that we are bound by that decision in this case." 44

The substantive defence in the Ashley Colter case was a partial failure of consideration which is a breach of contract. Short delivery as was the case in Ashley Colter and the installation of a faulty sewage system as in the Edcal case are both breaches of contract. In both a contracting party received less than he was promised and in that sense there was a partial failure of consideration.

If it is conceded, as it must be, following the decision in the Ashley Colter case, that partial failure of consideration is not an equity attaching to a bill or note, there is no sound reason for treating a breach of contract as such an equity. McDermid, J.A. in his dissent in the Edcal case put it thus: ${ }^{45}$

In the case at bar it was argued that a claim for unliquidated damages in respect of the very contract out of which the note arose was a defect of title and that as the appellant took the note after maturity the appellant took the note subject to such defect. If partial failure of consideration is not a defect in title, as decided in Ashley Co!ter Ltd. v. Scott, supra, then in my opinion the claim for unliquidated damages in this case is not a defect even although it arises out of the very contract in respect of which the note was given. I would have come to an opposite conclusion if it were not for the decision of the Supreme Court in the above-quoted case.

McDermid J. apparently meant by his concluding words that apart from the authority of the Ashley Colter case which he regarded as binding on him, he was of the view that partial failure of consideration is a defect of title.

The Alberta Court disregarded the assumption of the Court of Appeal in Oscar Harris, Son \& Co. v. Vallarman \& $\mathrm{Co}^{.8}$ that breach

41 [1940] 1 All E.R. 185, 162 L.T. 212.

4: Edcal Industrial v. Redl \& Zimmer (1967) 60 D.L.R. (2d) 289 at 297.

43 [1942] 3 D.L.R. 538.

44 Edcrl Industrial v. Redl \& Zimmer (1967) 60 D.L.R. (2d) 289 at 297.

45 (1967) 60 D.L.R. (2d) 289 at 299.

40 [1940] 1 All E.R. 185, 162 L.T. 212. 
of contract in supplying defective goods is a partial failure of consideration. It would appear also from the remarks of Parke, B. in Warwick v. Nairn ${ }^{47}$ during the course of the argument in that case that he may have regarded a breach of contract in supplying goods of deficient quality as a partial failure of consideration. It must not be overlooked that in both of these cases the action was between immediate parties and the real issue was a procedural one, as to whether the defence of partial failure of consideration could be raised in the same action. They are no support to an argument that either a partial failure of consideration, or a breach of contract whether or not it can rightly be deemed a partial failure of consideration, is a defect of title.

If there had been a finding of fact in the Edcal case that the person taking the note after maturity had known of the breach of contract, an argument might have been advanced that receiving the instrument with such notice was in the nature of fraud, which, under the Act, is a defect of title. In Oulds v. Harrison, ${ }^{48}$ an argument of this nature was raised with respect to a claim of set-off between the original parties on a bill of exchange. The plaintiff had taken the bill when it was overdue, apparently with notice of the existence of the set-off. Parke, B. rejected the argument that this constituted fraud, by saying: ${ }^{49}$

Notice of the existence of the set-off to the holder of the bill at the time it was due makes no difference, as was settled in Whitehead v. Walker (10 M. \& W. 969), unless, indeed, express notice was given by the party liable, and evidence of acquiescence in it, such as would amount to proof of an agreement to set off by both parties, which would be a satisfaction of the bill independently of the statute of set-off.

This being clearly settled, what is the effect of an indorsement of an overdue bill under the circumstances mentioned in the plea? These though inaccurately stated, we think, amount to an averment, that both the indorser and indorsee, knowing that there was a debt due to the defendant, which would be set off if the action should be brought by the indorser against the defendant, in order to defeat that set-off, and fraudulently, so far as that was a fraud but no further, agreed that the bill should be indorsed, and it was therefore indorsed, without value, to the plaintiff.

Though the plaintiff gave no value, the bill by the indorsement is transferred to him, and he has a right to sue on the bill if any intermediate party is a holder for value. There is, therefore, no defect in his title on that account. The only question then is, does the supposed fraud vitiate it; and in what way? Is it really a fraud, though called so? We think it is no fraud.

The position of a remote party taking an overdue bill of exchange or promissory note is an anomalous one. While the transmissibility of title to an overdue instrument is fully recognized in the scheme of things, the rights of a person to whom it is transmitted after maturity are subject to the equities of the instrument, except where the circumstances are such that he can shelter under a holder in due course. In the development of the law prior to the enactment of the Bills of Exchange Acts, it is clear that the only equities that attached to the instruments were basically those that arose at its inception or subsequent negotiation. The defects of title enumerated in the legislation, while not exclusive of others, are all of the same character. Not all equities cling to the instrument and it is submitted that any extension to include all the equities that existed between the parties to the underlying contract is an erroneous interpretation of the law. 